\title{
Beyond Ethnic Entrenchment and Amelioration: An Analysis of Non-Sectarian Social Movements and Lebanon's Consociationalism
}

\begin{abstract}
Research on consociational power-sharing divides on whether it provides a successful model for peacebuilding or instead exacerbates antagonistic ethnic divisions. In these debates, nonsectarian movements are either invisible or rendered as actors marginalized, co-opted, stripped of agency and disempowered by power-sharing. This article moves the focus away from 'either' 'or' analyses of consociationalism measuring its capacity to entrench or weaken ethnic divisions. Alternatively, it examines the different ways power-sharing effects a range of issues and groups and the varying modes of engagement generated by non-ethnic social movements in response. Power-sharing creates various dynamics that can result in either hegemonic compliance, constructive engagement, or active resistance by social movement actors that cross-cut ethnic cleavages. Using Lebanon as a case study, the paper examines movements that deal with sexuality, privatization and public goods, issues that are shaped by consociational institutions but rarely incorporated in power-sharing research.
\end{abstract}

Keywords: Consociationalism; power-sharing; Lebanon; social movements; peacebuilding; LGBT rights 


\section{Introduction}

Consociational power-sharing represents a major tool to manage conflict in ethnically divided societies. In contrast to previous strategies which sought to create peace by creating homogenous societies, power-sharing accommodates the plural character of the state by offering guarantees of political representation to the adversarial ethnic groups (Lijphart 1998). Such is the prevailing orthodoxy among the international community regarding consociationalism's propensity to build peace and democracy, it is used or prescribed for Bosnia, Lebanon, Northern Ireland, Burundi, Macedonia, Afghanistan, Kenya, Syria and Iraq. Yet, scholarly debates divide acrimoniously on whether 'consociational institutions offer a viable strategy to build peace, states, and democracy' (Wolff 2011, 1796) or if it aggravates 'the malady it is allegedly designed to treat' (Shapiro 1996, 102).

These polarizing narratives focus on consociationalism's consequences for the key ethnic divisions. For proponents, consociationalism endows strong prospects to eventually ameliorate belligerent ethnic identities that drive conflict (McGarry and O'Leary 1995; 2007; Nagle and Clancy 2010; Wolff 2011). Opponents label it an inept form of conflict management which dangerously reifies and separates ethnic groups instead of encouraging a shared civic identity (Horowitz 1985; Finlay 2010). In such discussions, however, nonsectarian groups are either invisible or rendered as actors that are marginalized, co-opted, stripped of agency and disempowered by power-sharing (Finlay 2011; Clark and Salloukh 2012). By privileging the identities of the main ethnic groups, consociational institutions, according to Finlay $(2011,10)$, 'close down the space for other ways of being, other ways of being political, other forms of political conflict'.

While we undoubtedly need to be careful when crafting institutions to end violent conflict (Wolff 2011), consociational arrangements may expedite uncertain outcomes and opportunities often unintended by the architects of these measures. This paper contributes to 
an understanding of these effects by examining the intertwining limitations and opportunities afforded by power-sharing and the forms of engagement created by non-ethnic movements in response. Power-sharing engenders dynamics that can result in either hegemonic compliance, constructive engagement or active resistance by social movement actors cross-cutting established ethnic cleavages.

Although research on power-sharing largely concentrates on its impact on the salient ethnic groups specified in arrangements (Horowitz 1985), power-sharing also creates consequences for social groups whose primary political identities resist alignment with the societal cleavages that consociations primarily accommodate. These groups include feminists, socialists, migrants, sexual minorities and a range of individuals refusing to be placed within bounded ethnic communities (Nagle 2013). Yet, rather than see these movements as actors silenced by consociational forces, they interact with power-sharing and even promote plural identities and political action that provide alternatives to ethnic communalism.

These issues are illuminated by looking at Lebanon's post-war consociational institutions, which guarantee representation for the state's main groups in the polity. Lebanon's consociational institutions are critiqued for creating dysfunctional political institutions (Salloukh et al 2015); for entrenching antagonistic ethnic divisions (Haddad 2009); and for encouraging corruption and clientelism (Leenders 2012). Although these critiques are valuable, they risk missing the multidimensional aspects of power-sharing that provide variable opportunities for non-sectarian forms of mobilization. In this paper I move the focus away from binary analyses consociationalism measuring whether it uniformly entrenches or weakens ethnic identities. Alternatively, I examine the different ways powersharing impacts on a range of issues and groups and the modes of engagement generated by non-ethnic social movements in response. 
Contemporary Lebanon contains a wide diversity of non-sectarian movements, embracing feminists (KAFA), secularists (Laïque Pride), and victims (Families of the Disappeared). In this paper, however, I limit the focus to movements mobilizing on issues concerned with sexuality, privatization, and public goods. I examine these three non-sectarian movements since they expose the significant consequences of contemporary power-sharing on a range of social and political issues that are not incorporated into existing studies of consociationalism. Consociational institutions simultaneously give and regress opportunities for Lesbian Gay Bisexual Transgender (LGBT) rights. On the one hand, power-sharing, which is based on constitutional rights to protect ethnic minorities, theoretically permits space for sexual rights. ${ }^{1}$ On the other, consociations can disavow such possibilities by empowering ethnic hardliners who promote particularistic policies demonizing sexual minorities. Social movements opposing the privatization of urban space illuminate how this process buttresses segregation and ethnic divisions (Nagle 2009). Finally, movements concerned with public goods reveal the degradation of such resources through the clientelistic and corrupt practices of sectarian leaders.

While power-sharing creates these effects, I note three broad forms in which nonsectarian movements engage with power-sharing: hegemonic compliance, constructive engagement, and active resistance. Hegemony refers to how dominant groups project their own way of seeing the world that becomes 'common sense' (Laclau and Mouffe 2001). In power-sharing, hegemonic compliance captures how the sectarian divisions sustaining the consociational system are seen as 'natural', thus legitimating the authority of ethnic elites. It is common for political elites in Lebanon to frame power-sharing as reflecting primordial, unchanging ethnic identities and as a system that guarantees the state's peace and security (see Nagle 2016a). Non-sectarian social movements grant hegemonic compliance when they paradoxically reproduce the logic of the sectarian system. Clark and Salloukh (2013) note 
contrasting ways that some non-sectarian social movements reinforce power-sharing. On the one hand, some nominally non-sectarian movements are designed to replicate power-sharing, such as the membership of the Lebanese Council of Women, which mirrors the 50/50 quota system used for power-sharing (Clark and Salloukh 2013). On the other hand, sectarian elites engage in strategies to co-opt and infiltrate non-sectarian movements, especially through clientelistic behaviour, so that these movements become de facto auxiliaries of the ethnic political parties. Constructive engagement differs from hegemonic compliance in that rather than bolstering the consociational system non-sectarian movements use opportunities provided by power-sharing to achieve significant reform or policy change. Active resistance is when non-sectarian movements use protest activity to radically confront and challenge the negative consequences of consociationalism.

In examining three movements dealing respectively with sexuality, privatization, and public goods, I explore how and where they generate hegemonic compliance, constructive engagement, and active resistance. Notably, in some of the movements we find all three outcomes and in some movements one feature predominates. Hegemonic compliance, constructive engagement, and active resistance characterize the response of sexual minority activists, while movements related to privatization and public goods articulate active resistance to power-sharing. This divergence can be explained by the complex set of opportunities and limitations specifically offered to sexual minorities by power-sharing which will be explored fully later. These contrasting dynamics expedite various responses by the LGBT movement, which is riven by splits as some aspects of power-sharing reward particular actors within the movement while simultaneously penalizing other members. Movements mobilizing over privatization and public goods, however, tend towards radical opposition to power-sharing since the sectarian system is framed by activists as providing 
little prospect for reform in its current format. For this reason, activists involved in privatization and public goods often intersect by forging networks for collective protests.

This research stems from four fieldwork trips to Lebanon (September 2012, July 2014, June 2015, and January 2016). Semi-structured interviews (N-30) were conducted with political representatives from the main parties and with human rights focussed non-sectarian social movement members. Interviews included political representatives from Amal, Kataeb, Lebanese Forces, the Future Movement, the Free Patriotic Movement, and the Progressive Socialist Party. Social movement activists included Helem (LGBT), You Stink (anticorruption), the Civil Campaign to Protect the Dalieh of Raouche (public space), SOLIDE, and ACT (victims' groups), UMAM Documentation and Research (memory). Interviews with activists were primarily designed to understand how they conceptualize the consequences of power-sharing and to understand the mobilizing strategies they developed in response.

\section{Consociationalism and Peace}

Consociational theory was originally developed by Arend Lijphart (1977; 1998), who noted that many societies divided by conflictual ethnic cleavages developed a system to sustain democratic stability and peace. Consociationalism is seen as fostering conflict resolution through the accommodation of the political elites representing the salient ethnic segments of society, and institutionally anchored by inclusive coalitions, constitutional vetoes, community autonomy, and proportionality in public appointments (Lijphart 1977; Horowitz 1985; Haddad 2009; Wolff 2011; Hanf 2015). Yet, while consociations once resulted from informal agreements between communal elites, they are now more commonly formalized in post-war constitutions. In assuring ethnic minorities representation in government, consociationalism aims to transform a zero-sum game for political power into one that encourages cooperation and compromise among elites that will eventually lead to the softening of ethnic divisions (Kerr 2005, McGarry and O’Leary 2007). 
Consociational institutions, however, cannot be expected to foment uniformly predictable outcomes for ethnic cleavages. This is because consociations rarely come in an identical template; instead, institutions are often crafted to accommodate the specific exigencies of power in the divided society (Wolff 2011). One reason for variance is that some consociations are designed to give the constituent groups stronger assurances of representation compared to others. Lijphart (1998) noted that in many consociations the constituent groups are given 'pre-determined' representation via fixed quotas for the allocation of government and public sector positions. In pre-determined consociations, it is assumed that 'group identities are fixed, and that groups are both internally homogeneous and externally bounded' (McGarry and O’Leary 2007, 675). Such consociations threaten to 'further entrench and institutionalise ... ethnic identities' (Wolff 2011, 1783). Corporate power-sharing therefore represents a very powerful mode of institutionalizing group identity in public life. While specific rights are granted to the main ethnic groups, a range of less powerful identity groups - typically with cross-cutting membership - are left outside the realm of representation, including feminists, migrants, secularists, and sexual minorities, meaning that individuals disidentifying from ethnicity have little right of exit (Nagle 2016a). Indeed, Lijphart (1998: 147) noted that the Lebanese system is 'inevitably discriminatory' against 'individuals or groups who reject the premise that society should be organized on an ethnic or communal basis'.

\section{Lebanon's Consociationalism, Institutions and Critical Agency}

Lebanon is a pre-determined consociation in which ethnic representation is guaranteed throughout political and public institutions. The logic of fixing ethnicity in power-sharing stands on a set of interlocking principles: the nation contains a high level of ethnoreligious diversity; this pluralism, if not institutionally accommodated, leads to intergroup conflict; and 
power-sharing should involve the elites of the major ethnoreligious groups (Picard 2002; Kerr 2005; Zahar 2005; Haddad 2009; Hanf 2015). Lebanese power-sharing, therefore, provides a system designed to manage conflicting visions of belonging over the very state itself (Zahar 2005). After the civil war, which caused 144,000 deaths, the Taef peace accord (1989) restored consociationalism to Lebanon by addressing its previous failures and by accommodating a new post-war balance of power (Kerr 2005). The Agreement's ethos - 'no victor, no vanquished' - meant that no group could exercise dominance over the rest within an intricate institutional apparatus of checks and balances (Hanf 2015).

The Taef Agreement envisaged power-sharing as a provisional step towards ending political sectarianism and even specified measures to ensure this goal, including making the election of politicians 'on a national, not sectarian, basis' (Rosiny 2015). However, these measures have not been implemented and Lebanon's consociationalism - known as confessionalism $^{2}$-is deployed to cement ethnic cleavages. The concept of the 'allotment state' ('muhasasa') means that each group is guaranteed representation through a quota system reflecting the assumed demographic balance (Leenders 2012). At the executive level, the positions of president, prime minister and speaker of the house - the troika - are reserved for Maronite Christians, Sunnis, and Shiites respectively. The quota system is applied to cabinet positions, seats in the national parliament and reproduced across the security forces, banking sectors, judiciary and public administration (Salloukh et al 2015). Group boundaries are reinforced by 'segmental autonomy': Articles 9 and 10 of the constitution devolve legal authority to the religious leaders of the groups over a range of personal matters, including marriage, divorce and child custody rights (Haddad 2009).

While Taef's drafters framed Lebanon's consociational arrangements as a 'covenant of mutual coexistence', power-sharing is identified by a number of scholars as creating negative outcomes. Lebanese 'consociationalism [has] tended to promote the growth of 
polarization' (Kassir 2011, 445) as it 'has failed in its task of providing stable and properly functioning public institutions' (Haddad 2009, 414). These weaknesses have allowed sectarian elites - often former warlords - to degrade public goods and to capture, via clientelism and corruption, economic and political institutions (Leenders 2012). These internal flaws, furthermore, make Lebanon vulnerable to regional instability as powerful external actors seek to exploit the state's fragility by co-opting local partners as part of a wider regional proxy war (Zahar 2005). Finally, Lebanese consociationalism 'is deployed instrumentally by a sectarian/political elite bent on reproducing sectarian identities and obviating the emergence of alternative, transsectarian or non-sectarian, modes of political mobilization' (Salloukh et al 2015: 2).

The institutional effects of Lebanon's power-sharing harden sectarian identities. However, such institutions, no matter how much they are utilized to determine ethnic identity, are never coherent, exhaustive or closed in the ways they are imagined as being. They are instead infused by elisions and systemic weaknesses, which allow some opportunities for non-sectarian movements to engage with or radically oppose power-sharing. Research on consociationalism and divided societies somewhat assumes the unidirectional relationship between consociational institutions and ethnic identity outcomes. Utilizing the Foucauldian language of biopolitics, Finlay (2011) argues that consociationalism actively operates to 'make ethnicity itself normative'. Institutions certainly do have the power to shape social identity, including ethnicity, and categorization contributes 'to the production of people, identified in a particular way' (Jenkins 2004, 161). Yet, as Brubaker (2002, 168-169) notes, while there may well be highly salient ethnic categories that are 'institutionalized and entrenched in administrative routines ... high levels of groupness may fail to crystallize'.

Powerful institutions, therefore, do not simply construct ethnic categories and determine groupness. This is not surprising. The law of unintended consequences - outcomes 
not meant by purposeful rational action - is a long-held axiom of sociological research on institutional design. Even Foucault $(1999,162)$ recognized that governance institutions do not construct power as ubiquitous and insidious. Rather than seeing governance as creating 'individual copies that are mechanically punched out' (Habermas 1987, 293), forms of 'subversive agency' exist which elude or resist the interests of power. This nexus connecting subversive agency to institutions is exposed, in the case of consociationalism, by nonsectarian social movements.

\section{Sexual minorities: Co-option, Access and Radical Resistance}

Lebanon's sexual minorities are subject to Article 534 of the Lebanese penal code which bans sexual relations that supposedly 'contradict the laws of nature' (Naber and Zataari 2014, 109), a decree introduced as part of formalizing power-sharing (Makarem 2011). Powersharing impacts on sexuality in Lebanon through the application of group autonomy. To preserve Lebanon's diversity, power-sharing devolves authority over 'morality' to religious leaders via 15 separate personal status laws, the consequence of which is to legitimize the oppression of women and sexual minorities. According to one Lebanese LGBT movement, the sect leaders 'want to purify the world of homosexuality' (Meem 2010, 7), and for an

LGBT leader, 'the confessional system has always been opposed to us' (personal communication, June 2015).

For Lebanese activists, a key question is to how to design mobilizing strategies for the LGBT population in relation to power-sharing. Addressing this is Helem, which became a public movement in 2004 and is identified as the first LGBT rights movement in the Middle East and North Africa (Makarem 2011). A central dilemma confronting Helem and other LGBT groups was whether or not to seek rights within the consociational system. As recognized by activists, 'there is very little space for the protection or expansion of gay rights 
within the sectarian system in Lebanon'. Power-sharing instead 'is the greatest object standing against the homosexual identity' (Meem 2010, 12). In particular:

how does one advocate for gay rights in Lebanon? Suppose the government did want to expand gay rights, how would they even do that? Any effort to reform laws and practices towards expansion of gay rights would have to negotiate independently with each religious community because ... any major political development in Lebanon requires the support of all the various sects (Meem 2010, 17).

Another leading LGBT activist explained how power-sharing stymies the capacity for political and social transformation:

the confessional system in Lebanon is designed in a way with which to make it incredibly hard for change to happen and that renders it intrinsically homophobic, racist, sectarian. The confessional system legitimized sectarianism in the minds of the Lebanese public as something matter of fact. It has unfortunately made a lot of mobilization for a lot of causes very problematic simply because sectarianism is a very easy card for a lot of Lebanese decision makers to play with to exonerate their own position, to excuse their own mistakes, and to rally support (personal communication, June 2015).

Despite consociational institutions restricting sexual minority rights, LGBT movements dynamically interact with and even advance a radical form of opposition to power-sharing. However, the question of whether and how to engage with or to oppose the political sectarianism of power-sharing generated divisive opinion and even splits within the LGBT movement. In terms of engaging with power-sharing, a Helem activist explained: 'the only way to navigate such a sectarian system is to create a sect; if you become separatist you will receive your rights' (personal communication, June 2015). Although it is not feasible for sexual minorities in Lebanon to become a recognized sect, some sexual minority activists acknowledge that 'The LGBT movement will face it. The confessional system can absorb anything in Lebanon; it's in its own interests to do so' (personal communication, June 2015).

In this way, consociationalism encourages hegemonic compliance with its norms. An LGBT activist noted that it is almost impossible to remain outside of the power-sharing 
apparatus: 'Our movement is sectarian in the sense that it is sucked into the clientelistic system and funding and donors are a very big factor' (personal communication, June 2015). While the movement are not clients of any of the main sectarian parties, many receive resources from international human rights groups. As such, a political representative of an ethnic party accused the LGBT movement of reproducing power-sharing by creating sect identities: 'the head of a civil society movement in Lebanon acts like a sectarian leader ... they cultivate a cult like mentality' (personal communication, July 2014).

Power-sharing also provides unintentional opportunities for complex forms of constructive engagement. An LGBT activist explained that for Lebanon's sexual minorities 'the confessional issue impacts everything ... Not all of this is negative' (personal communication, July 2014). The principle of communal autonomy mentioned earlier, which distributes power to elites at the local level, paradoxically provides a limited degree of freedom for sexual minorities. With autonomy, the main ethnic groups in Lebanon are cautious of intruding in the internal communal matters of other groups as this would be in contrary to the spirit of peaceful coexistence undergirding power-sharing. This has consequences for sexual minorities: while there is state harassment of sexual minorities in the public domain, to some extent sexual minorities are tolerated as long as they remain private. An activist noted:

the sectarian divide has allowed for gay people to seek refuge in another part of town to escape discrimination ... This anonymity in Beirut, whereby if you're not part of my congregation, you're not part of my family, you're not part of my village, most probably I am not going to care and even if I care I am going to think twice about coming to your house and kicking you out because you are of a different confession (personal communication, July 2014).

However, this private sphere is permitted only to privileged sexual minorities, especially middle-class men, a situation which exposes how power-sharing expedites opportunities and 
constraints for different members of the LGBT community. A consequence of the powersharing system granting middle-class men some 'communal autonomy' is that it may disincentivize them from engaging in a rights-based mobilization. A Helem activist noted:

The particular layout of this country means it is possible if you have access to resources and contacts to exist as a gay person in Lebanon and to be fine. You have got your gay bars; the police don't arrest you, they arrest Syrian refugees, trans-people, sex workers and drug users, the invisible part of the country that we work with, so there is no impetus for people to go down onto the street (personal communication, June 2015).

A Helem activist described the situation as de facto state co-option: 'it is a vicious circle of spaces opening up and closing down' (personal communication, July 2014). While limited gay spaces exist in Beirut, the potential for an activism that challenges oppression is blocked. Middle-class gay men, radical activists argue, are complicit in the act of co-option by the state. Although many Lebanese movements are internally fractured on class lines, this situation is particularly acute for the LGBT movement. The splintering of the LGBT movement on class lines indicates how power-sharing can expedite different sets of opportunities and penalties for members of the same movement. These dynamics, in turn, lead to significant divisions among activists regarding mobilizing strategies, between those who are seen as engaging in hegemonic compliance as a way to gain rights and those who oppose what they see as a sectarian system that sustains oppression against sexual minorities. For example, a vociferous debate has occurred among activists about whether the small number of LGBT bars in Beirut should be used as safe but invisible spaces or if they should provide the basis for political activism. A former Helem leader recounted:

wealthy men thought that there were privileges from having such spaces and thought that if we start opposing the state they [the state] might do something. And you always have to deal with this type of balance: confronting injustice could lead to a backlash from the state (personal communication, June 2015). 
Yet, notwithstanding the obvious structural obstacles placed by power-sharing institutions on LGBT mobilization, Lebanese sexual minority activists provide constructive forms of engagement with power-sharing that fosters policy change. Institutional dysfunctionalism, paradoxically, afford openings for LGBT movements to advance radical politics and to position themselves as providers of key services. Periodic crises blight powersharing institutions as ritual rounds of policy deadlock bring them to the point of collapse. Such logjams arise from a power-sharing structure that allows ethnic elites to pursue politics designed to protect communal interests (Leenders 2012, 224). Thus, when one or more of the factions view certain policies as harming their communities' interests, they deploy their communal veto. The dysfunctionalism of power-sharing exposes momentary fissures to permit non-sectarian social movements to successfully operate in the vacuum. An LGBT activist explained:

\footnotetext{
The confessional system means that the state that will never be in control, so what the state needs to do is to have some form of consensus between the sects and everything will be ok. The way the sectarian system works is that you have clashes between the sects, between the status of the state institutions, and it is purely on a sectarian basis. This is the clash that creates some spaces for us (personal communication, June 2015).
}

As the state lacks complete control, this allows limited prospects for movements to pursue radical policies and events. For example, the LGBT movement hosted impromptu gay film festivals and protests at times when the state is relatively powerless to intervene. Although not an ideal environment for stability and peace, some social movement activists view state dysfunctionalism as preferable to the successful operation of political sectarianism. An activist explained: 
education. So civil society I would argue has never been more important (personal communication, June 2015).

This institutional dysfunctionalism permits opportunities for Helem's activists to operate unofficially with some key state actors, including the security forces, health workers and schoolteachers. Thus, the movement often works behind the scenes to improve conditions for sexual minorities, particularly with the judiciary and the internal security forces, 'so we create some sort of an understanding, not necessarily a law, but a procedure, an understanding, a relationship' (personal communication, September 2012). Such activism has led to important reforms. Helem have become the Ministry of Public Health's 'invisible partner' in HIV testing and screening (Salloukh et al 2015, 56) and they also successfully persuaded members of the judiciary not to apply Article 534 as it rests on an unclear definition of human nature.

While institutional dysfunctionalism creates fissures for sexual minority activists to operate, radical opposition to power-sharing exemplifies the protest politics of many LGBT activists. Some activists view 'Lebanon's sectarian structure ... as a key site of struggle not only because it is divisive ... but also because it is patriarchal and requires compulsory heterosexuality' (Naber and Zataari 2014, 100). This opposition to power-sharing is evident in the statements of movement activists. For one Helem activist, a fundamental objective of the LGBT movement is 'fighting to end confessionalism of the political system' (Makarem 2011). A lesbian movement identified one of its major goals as 'resisting sectarianism', since 'the biggest challenge to any form of social justice in Lebanon is the sectarian makeup of its society' (Meem 2010, 15). In identifying power-sharing as censoring non-heterosexuality, radical Lebanese activists oppose it. LGBT resistance, therefore, is articulated through rejecting a sectarian identity (Naber and Zataari 2014, 103). Helem's development as an 
'anti-imperialist movement led to the adoption of an anti-sectarian, anti-racist, and antixenophobic position' (Makarem 2011, 105).

\section{'Pie-sharing', Privatization and Amnesia}

In accommodating conflicting ethnoreligious groups, Lebanese power-sharing came to be dominated by informal bargaining between elites. The most common outcome of this process is the apportionment of the spoils of public office, privileges and state resources between sectarian elites (Leenders 2012, 179-80). A social movement activist explained that rather than power-sharing, the system is better termed 'pie sharing' as it reflects the capacity of elites to appropriate and divide resources for their individual and collective enrichment (personal communication, July 2016). A consequence of pie sharing is that public resources are subject to privatization strategies, which are, in turn, placed under the remit of the sectarian allotment system that undergirds power-sharing.

The relationship between power-sharing and privatization strategies is evident in the post-war reconstruction of Beirut city centre. The regeneration of Beirut city-centre was initiated in 1991 by Law 117 deliberately passed to enable reconstruction. Under Law117, a real estate company, Solidere, formed to redevelop what it termed 'Beirut Central District' in the name of public interest. Owned by Rafiq Hariri, the Lebanese Prime Minister, Solidere was permitted special powers of compulsory purchase and regulatory authority by the government. Operating as a 'private-public hybrid' entity, Solidere represents the 'colonization' of the public sector by the private, and the 'dissolution of any real distinction between public and private interests' (Makdisi 1997, 672). Assets held by more than 120,000 original claimants to property rights in the area were transferred to Solidere (Leenders 2004, 183), and Solidere have redeveloped 200 hectares of land. The properties gained by Solidere 
are, by their own estimates, worth $\$ 8$ billion (Solidere 2011, 7), approximately one quarter of Lebanon's GDP.

The reconstruction of the city-centre corresponded to the 'allotment state', in which resources and positions are distributed on a sectarian basis as Solidere compensated the representatives of the main ethnic parties (Roy 2009, 170-171). Yet, crucially the reconstruction process had a role in maintaining power-sharing not clearly intended by the sectarian elites. The reconstruction process was originally framed as constructing a conflictfree zone to symbolize Lebanon's ability to overcome its divisions (Makdisi 1997, 675). Solidere (2011, np) announced that it "is vested with a ... historical mission: restoring life to this vital part of the country, an important political and symbolic dimension', which contributes to national reconciliation.

The rebuilding of Beirut city-centre was critical to peace since it had the promise to be a rare shared public sphere in a society where urban space is increasingly sectarianized or made exclusive to rich elites (Nagle 2016b). The city centre's potential to represent a relatively cosmopolitan public space in a society riven by sectarian segregation was due to its status as a place of mixing prior to the civil war. Beirut city-centre before the war afforded some protection against the prevalent forces of ethnic separation and intolerance that led to conflict (Khalaf 2012). A social movement activist reminisced:

Downtown Beirut was a place where you could not go to and stay entrenched in your confessional identity. It was a place where people needed to adjust to the fact that they are there with others who don't have the same colloquial perspective, who don't have the same beliefs, don't have the same origin but they needed to interact with (personal communication, June 2015).

However, the post-war reconstruction of the city-centre had the opposing effect of legitimating sectarian and socioeconomic segregation. An activist noted:

The urban idea of Solidiere - turning the downtown of Beirut into a kind of exclusive touristic resort has contributed to keeping the confessional system. The Lebanese need meeting points. What did we 
do in order to create physical and social meeting points since 1990 ? Nothing. This kind of savage privatization of the public space is just contributing to keeping the entrenchment and engulfment of each community (personal communication, June 2015).

A particular way that the city-centre reconstruction buttresses this nexus between power-sharing and segregation is via the application of amnesia. For a number of critics (Makdisi 1997; Haugbolle 2010; Kassir 2011; Khalaf 2012), Solidere's rebuilding of the citycentre represents 'a desire for collective amnesia, wiping away all reminders of the conflict' (Wainwright 2015). This amnesia also acts to obscure the city centre's historical purpose as fostering public engagement and interaction. As one social movement activist noted: 'the downtown is the core of the reconstruction ideology ... it is very simply part of the amnesia'. Another activist explained:

In 1992 the Solidere project came around and for me, it was just a catastrophe, it was part of a plan to erase memory and when you erase the memory of the downtown it is the most destructive thing that you can do to a city (personal communication, June 2015).

The exercise of amnesia links to power-sharing in a crucial way. Sanctioned by the Taef Agreement, 'a strategy of oblivion was imposed in order to let the social system in place prevail' (Haugbolle 2010, 70). This elite-led social forgetting about the civil war was shaped by the resumption of power-sharing. Power-sharing was designed to allow the sectarian warlords to transition into political leaders. Recognizing that they would have been prosecuted for war crimes, in 1991 the sectarian elites passed a general amnesty Law 84 which selectively pardoned 'political crimes' committed during the civil war (Picard 2002, 165). As one activist for victims explained:

When you know very well that all of the big projects undertaken in this country were just strengthening the rule of those former warlords who whitewashed their records thanks to Taef. You cannot tell me that with these people who promoted the religion of amnesia you can really build peace? (personal communication, June 2015). 
Yet, the desire of the sectarian elites to enforce social forgetting is incomplete. Social movements programme memory back into the city as a mechanism to demand access to public spaces and as a means to request municipal services in the present. There are different types of social movement actors opposing the narratives of amnesia embedded within postwar reconstruction and privatization projects. In resisting the expropriation of city centre space, rather than inspire hegemonic compliance or constructive engagement, these protest movements articulate active resistance.

One type of activism is concerned with protecting the city-centre's architectural heritage. One building, the Yellow House, which was used by militia snipers during the civil war, was expropriated by Solidere and scheduled for demolishment. In 2003 activists successfully forced the municipal authorities to seize the Yellow House so that it could be converted into a 'Museum of Memory for the City'. The campaign to use the museum as a site to remember the war is also seen by activists as a struggle against the capture of the city by private agencies and sectarian elites:

I was fighting against the people who thought that it's not worth preserving. The struggle to try and get the museum built symbolizes post-war Beirut, the fight against amnesia, the fight to preserve memory against money, the fight for history and identity that we are still facing every single day because we have no government and no hope (personal communication, June 2015).

Another movement campaigned to stop the privatization of key public areas, such as Beirut's natural shoreline. A law in 1995 allowed Solidere to reclaim nearly 800,000 square metres of Beirut land from the sea. About 100,000 square metres incorporate the Dalieh of Raouche, a natural heritage site on Beirut's shoreline. In early 2013 the entrance to Dalieh was blocked as a prologue to the land being transformed into a private beach club. In March 2013, 40 activists working on environmental and public space issues and maritime protection 
met to discuss stopping the privatization of Dalieh. One of the campaign organizers explained:

We were all aware of the issues and the controversies that took place after the civil war with the loss of centrality and the loss of gathering places and the increasing of private spaces and the encroachment on shared spaces and city's livability (personal communication, June 2015).

The campaign - known as the 'Civil Campaign to Protect the Dalieh of Raouche' utilizes memory as a key form of protest politics. The movement illuminates the memory of an 'open access shared space' for a wide variety of city dwellers" regardless of the identity groups they may belong to. Through numerous protests, the campaign forced the city's municipality to stop the redevelopment. Moreover, through using memory to resist amnesia, these movements confront and take responsibility for the failures of the democratic state and power-sharing.

\section{Corruption, You Stink and the Twilight of the Gods}

As part of the 'pie sharing' system in which the spoils of state are divvied up, lucrative contracts for public works are awarded to private companies with close ties to sectarian elites (Leenders 2012). Sectarian leaders and their parties are able to advance rent seeking through informal elite level bargaining. However, at times of political conflict one or more of the elites can depart from the system of tacit cooperation thus infecting power-sharing with institutional dysfunctionalism. Forty-four parliamentary sessions failed to elect a new president, elections are constantly delayed and political appointments for the head of the military, central bank and judiciary - positions distributed on a sectarian basis - have been postponed (Nakhoul 2015). This dysfunctionalism also creates chronic problems for the production and distribution of public goods. Illustrative of this situation is refuse collection, which became the source of a major protest movement in 2015. 
Rather than administered by the state via municipal councils, refuse collection was delegated to the private sector after the end of the civil war. In 1994, the government contracted a private company - Sukleen - to manage Lebanon's refuse collection and disposal at more than twice the standard going rate (Kingston 2013). A former managing director of Sukleen acknowledged that the patronage of Rafiq Hariri, then the leader of the Future Movement and Prime Minister, was instrumental to the company winning the contract (Leenders 2012). The relationship between the Future Movement and Sukleen provided fuel for political opponents claiming to take a stand against government corruption (Zbeeb 2012). While Sukleen's contracts were renewed in 1999 and 2010 as the result of elite trade-offs (Zbeeb 2012), in July 2015 the power-sharing government, stuck in fierce political deadlock over the election of the president, refused to extend the contract resulting in more than 20,000 tonnes of uncollected rubbish in Beirut.

A non-sectarian protest movement - 'You Stink' - formed in response to the 'trash crisis' and proceeded to gather protestors in Beirut city centre to demand the government's resignation for allowing sectarian differences to supersede the public's environmental and health needs. Many protestors - reported as 'people from across the sectarian and political spectrum' (Aljazeera 2015) - carried placards, symbolic refuse bags and wore paper masks to cover the stench of the trash and what they viewed as the decaying political class. For You Stink's activists the failure of the state to deliver key public goods is an outcome of the power-sharing system that incentivizes corruption and sectarian conflict. A leading activist explained that the sectarian elites 'are using the confessional system for their corruption, so it is a vicious circle and you have to find a way to stop it' (personal communication, January 2016). According to another activist, these elites purposely promote dysfunctionalism within power-sharing to stymie the development of civic politics:

you cannot build peace [with the elites] because their very strength is to prevent a fair, more or less modern state from emerging. Their strength comes from cultivating their networks with public money; 
their strength comes from their influence over the administration, over the army, over the security services, over the judiciary. How can we hope to build peace with people whose survival depends on maintaining a state of non-peace? (personal communication, June 2015).

In this context, You Stink's protests encompassed more than the issue of refuse collection; rubbish represented a potent symbol to capture the failings of contemporary power-sharing in the state. The You Stink movement drew resonance with many Lebanese as evidenced by the protests which attracted up to 120,000 participants in Beirut city-centre. These protests articulated opposition to how power-sharing is deployed to legitimate corruption and to diminish the public sector. Notably, in using the space of the city-centre as a venue for protests, You Stink connects to the campaign against the privatization of the downtown explored in the previous section. A You Stink activist proclaimed: 'We want to hold accountable everyone who robbed this country ... and we want to reclaim Downtown Beirut for the people' (Daily Star 2015).

A You Stink leader argued that the movement represented 'the silent majority that is disenfranchised, but they are not powerless' (personal communication, January 2016). In mobilizing this group, You Stink articulated a powerful alternative politics to the sectarianism reproduced by political leaders. You Stink, therefore, encourage 'cognitive liberation': the process through which activists inspire individuals to formalize shared understandings of their situation as one of oppression and marginalization so that they achieve groupness (McAdam 1982). Cognitive liberation does not end with the process of conceptualizing the structural issues that entrench social inequality; it further sustains the legitimacy required to stimulate the forms of 'active resistance' to sectarianism mentioned earlier.

While sectarian politics reproduces ethnic antagonism in Lebanon, You Stink encourages cross-cleavage alliances and a political sensibility that fosters civic interests. A leader explained: 
People are angry in Lebanon and what the politicians do is that they turn this anger toward the sectarian 'other'. What we try to do is redirect the anger at the actual culprits. For once we realise that our economic and our day-to-day anger shouldn't be directed at one another; it should be directed at the people in power and for us to make them accountable. As long as we keep redirecting the anger this might get the people to forget about their confessional background and go towards the higher goal: a better country for us all ... There is no such thing as confessional segregation unless it's in the mind of our politicians.

In redirecting the anger' of the public towards the political elites, You Stink activists reject the status of marginalized and disempowered actors unable to affect social and policy change against power-sharing. You Stink activists see the protests as fomenting significant opposition to a form of political sectarianism that incentivizes ethnic conflict, corruption and dysfunctional political institutions. For a You Stink leader, an important achievement of the movement is to break the 'god-like' stature of the ethnic elites:

they have been treated as gods for the past thirty years ... They are supposed to be held accountable when they fail and they have failed us miserably. We are killing off their god-like aspect and bringing them down to the ground and when you have them on the ground, you will beat them up (personal communication, January 2016).

Through challenging the 'aura' of the sectarian elites and the politics of dysfunctionalism and corruption that flow from power-sharing, rather than only aim to effect short-term political transformation, You Stink advances a long-term shift in civic consciousness and public discourse in which it encourages the wider society to adopt a politics that is not simply tied to ethnic identity (Murtagh 2016).

\section{Conclusion}

The ability of non-sectarian actors to transform state institutions in divided societies is circumscribed by the institutional effects of consociationalism. Yet, these movements can 
threaten the moral order of power-sharing and, in consequence, receive severe censure for so doing. A sectarian elite accused You Stink of representing 'an attempt to topple what is left of the institutions and the government, which would shake and endanger stability and civil peace' (Daily Star, 2015). You Stink responded that the allegation aimed to 'refute the idea of having an independent non-sectarian alternative' (https://www.facebook.com/tol3etre7etkom/posts/1631214497140665?fref=nf\&pnref=story). During demonstrations, the state security forces attacked the protestors with baton rounds, killing one protestor and injuring hundreds. For their LGBT activism, a politician charged Helem with 'corrupting the youth', and leading members were subsequently detained and interrogated by the security forces (Salloukh et al 2015, 62-62).

Rather than powerless actors, these examples attest to the potential of non-sectarian movements to challenge the authority of sectarian elites. Yet, to what extent do these movements effect political and social change to their advantage? If we were to use Gamson's (1990) criteria of 'acceptance' - the capacity of the state to cede to movement requests - then non-sectarian movements in divided societies appear to make little impact. The prospects for social movements to influence public policy are particularly bleak when these issues are bound up within ethnonational cleavages. The intensity of ethnic cleavages in divided societies means that practically all issues become points of extreme ethnocommunal polarization (Horowitz 1985). Protests against the government over public services or to oppose private interests regenerating public space can quickly be seen as anti-state or possessing a sectarian veneer.

Consociational institutions may reinforce this situation by prioritizing the rights and interests of the main ethnic groups, which limits the facility of non-sectarian actors to access the system and advance policy reform (Finlay 2010). Yet, this paper highlights the complex ways that power-sharing simultaneously induces and inhibits various forms of engagement 
from Lebanese non-sectarian movements. These modes of engagement should not be seen as uniformly positive or negative but instead arrayed on a spectrum of effects. In some situations, non-sectarian movements have become co-opted, especially by the norms of the power-sharing system that incentivizes clientelistic behaviour. In other contexts, nonsectarian movements expose gaps in the power-sharing structure sufficient to foment changes in public policy which benefits all individuals regardless of ethnic belonging. Non-sectarian movements, furthermore, can articulate powerful forms of protest and opposition to particular aspects of power-sharing identified as particularly harmful to wider society. This paper, therefore, provides a clarion call for further research that examines the relationship between consociationalism and non-sectarian groups in a range of divided societies. 


\section{Endnotes}

${ }^{1}$ For example, power-sharing constitutions and agreements in South Africa, Northern Ireland and Nepal provided legislative safeguards for sexual equality (Nagle 2016).

2 'Confessionalism' is used to describe the main cleavage as ethnoreligious. Although Lebanon's power-sharing officially recognizes 18 religious groups, there are 6 main groups: Maronite, Greek Orthodox, Armenian, Shia, Sunni, and Druze.

\section{References}

Aljazeera. 2015. "Lebanese Protest Against Waste-disposal Crisis.” Aljazeera, July 26. http://www.aljazeera.com/news/2015/07/lebanon-beirut-trash-rubbish-crisis150725060723178.html

Brubaker, R. 2002. "Ethnicity Without Groups." Archives Europeennes de Sociologie 43(2): 163-189.

Clark, J.A. and B.F. Salloukh. 2013. "Elite Strategies, Civil Society, and Sectarian Identities in Postwar Lebanon.” International Journal of Middle Eastern Studies 45(4): 731-749.

Daily Star. 2015. "PSP withdraws from YouReek Protest After Change in Demands." Daily Star, August 23. http://www.dailystar.com.lb/News/Lebanon-News/2015/Aug23/312361-psp-withdraws-from-youreek-protest-after-change-in-demands.ashx.

Finlay, A. 2010. Governing Ethnic Conflict: Consociation, Identity and the Price of Peace. Abingdon: Routledge.

Foucault, M. 1999. Religion and Culture. London: Routledge.

Gamson, WA. 1990. The Strategy of Social Protest. Belmont, CA: Wadsworth.

Habermas, J. 1987. The Philosophic Discourse of Modernity. Cambridge, MA: MIT Press.

Haddad, S. 2009. "Lebanon: From Consociationalism to Conciliation." Nationalism and Ethnic Politics 15(3-4): 398-416.

Hanf, T. 2015. Coexistence in Wartime Lebanon. London: I.B. Tauris.

Haugbolle, S. 2010. War and Memory in Lebanon. Cambridge: Cambridge University Press.

Horowitz, D. 1985. Ethnic Groups in Conflict. Berkeley, CA: University of California Press.

Jenkins, R. 2004. Social Identity. Abingdon: Routledge.

Kassir, S. 2011. Beirut. Berkeley, CA: University of California Press.

Kerr, M. 2005. Imposing Power-Sharing: Conflict and Coexistence in Northern Ireland and Lebanon. Dublin: Irish Academic Press.

Khalaf, S. 2012. Lebanon Adrift: From Battleground to Playground. London: Saqi.

Kingston, P. 2013. Reproducing Sectarianism: Advocacy Networks and Politics of Civil Society in Postwar Lebanon. New York, NY: SUNY Press.

Laclau, E. and C. Mouffe. 2001. Hegemony and Socialist Strategy: Towards a Radical Democratic Politics. London: Verso.

Leenders, R. 2012. Spoils of Truce: Corruption in Postwar Lebanon. Ithaca, NY: Cornell University Press. 
Lijphart, A. 1977. Democracy in Plural Societies: A Comparative Exploration. New Haven, CT: Yale University Press.

Lijphart, A.1998. "South African Democracy: Majoritarian or Consociational?" Democratization 5(4): 144-150.

Makarem, G. 2011. “The Story of Helem.” Journal of Middle East Women's Studies 7(3): 98112.

Makdisi, S. 1997. "Laying Claim to Beirut: Urban Narrative and Spatial Identity in the Age of Solidere." Critical Inquiry 23(3): 660-705.

Meem. 2010. Arab Queer Women and Transgenders Confronting Diverse Religious Fundamentalisms: The Case of Meem in Lebanon. Meem: Beirut.

McAdam, D. 1982. Political Process and the Development of Black Insurgency. Chicago, IL: University of Chicago Press.

McGarry, J. and B. O'Leary. 2007. "Iraq's Constitution of 2005: Liberal Consociation as Political Prescription." International Journal of International Law 5(4): 670-698.

Murtagh, C. 2016. "Civic Mobilization in Divided Societies and the Perils of Political Engagement: Bosnia and Herzegovina's Protest and Plenum Movement." Nationalism and Ethnic Politics 22(2), 149-171.

Naber, N. and Z. Zaatari. 2014. "Reframing the War on Terror: Feminist and Lesbian, Gay, Bisexual, Transgender, and Queer (LGBTQ) Activism in the Context of the 2006 Israeli Invasion of Lebanon." Cultural Dynamics 26(1): 91-111.

Nagle, J. 2009. "Sites of Social Centrality and Segregation: Lefebvre in Belfast, a 'Divided City."” Antipode 41(2): 326-47.

Nagle, J. 2013. “'Unity in Diversity': Non-sectarian Social Movement Challenges to the Politics of Ethnic Antagonism in Violently Divided Cities." International Journal for Urban and Regional Research 37(1): 78-92.

Nagle, J. 2016a. Social Movements in Violently Divided Societies: Constructing Conflict and Peacebuilding. Abingdon: Routledge.

Nagle, J. 2016b. "Ghosts, Memory and the Right to the Divided City: Resisting Amnesia in Beirut City Centre.” Antipode (Advance online publication).

Nagle, J. and M.A.C. Clancy. 2010. Shared Society or Benign Apartheid? Understanding Peace-Building in Divided Societies. Basingstoke: Palgrave MacMillan.

Nakhoul, S. 2015. "Lebanon's Rubbish Crisis Exposes Political Rot.” Reuters, September 7. http://www.reuters.com/article/us-lebanon-protests-crisis-insightidUSKCNOR70GO20150907

Picard, E. 2002. Lebanon: A Shattered Country. New York, NY: Holmes and Meir.

Roy, A. 2009. "Civic Governmentality: The Politics of Inclusion in Beirut and Mumbai." Antipode 41(1): 159-179.

Rosiny, S. 2015. “A Quarter Century of 'Transitory Power Sharing': Lebanon's Unfulfilled Ta' if Accord of 1989 Revisited." Civil Wars 19(4): 485-502. 
Salloukh B.F., R Barakat, J.S. Al-Habbal, L.W. Khattab and S. Mikaelian. 2015. The Politics of Sectarianism in Postwar Lebanon. London: Pluto.

Shapiro, I. 1996. Democracy's Place. New York, NY: Cornell University Press.

Solidere. 2011. Momentum of Place, People in Motion: City in Scenes. Beirut: Solidere.

Wolff, S. 2011. "Post-Conflict State Building: The Debate on Institutional Choice." Third World Quarterly 32(10): 1777-1802.

Zahar M-J. 2005. "Power-sharing in Lebanon: Foreign Protectors, Domestic Peace, and Democratic Failure." In Sustainable Peace: Power and Democracy after Civil Wars, edited by D. Rothchild and P. Roeder, 219-240. Ithaca, NY: Cornell University Press.

Zbeeb, M. 2012. "\$5 Million a Year: The Tip of the Sukleen Waste Pile." Al-Akhbar, August 27. http://english.al-akhbar.com/node/11479. 